\title{
THE RIGHT TO STRIKE AND OTHER FORMS OF PROTEST OF PERSONS PERFORMING GAINFUL EMPLOYMENT UNDER CIVIL LAW
}

\begin{abstract}
This article deals with the issue of extending the right to conduct a collective labour dispute to persons performing paid work under civil law contracts, after the entry into force of the Act of 5 July 2018 amending the Act on Trade Unions and Certain Other Acts (Journal of Laws 2018, item 1608). The author considers the question whether and to what extent the right to strike and to take industrial action, provided for in the Act of 23 May 1991 on Resolution of Collective Disputes (consolidated text: Journal of Laws 2020, item 123), extends to civil lawful contractors. The position is presented that the proper application of the above mentioned law to the indicated circle of work contractors cannot mean the deprivation or limitation of their right to strike and to take industrial action. The solutions implemented by the Polish legislator with regard to persons performing work outside the employment relationship are more advantageous and far-reaching in comparison with the requirements resulting from the international labour law acts binding on Poland. However, there are specific problems with applying to these persons some of the regulations included in the Act on Resolution of Collective Disputes. These problems results from the fact that the individual legal relationship between these persons and the entities employing them is based on the provisions of civil law, and not on the Labour Code.
\end{abstract}

Keywords: collective labour dispute, trade union, right to strike, industrial action, civil law contract, employment relationship.

\section{PRAWO DO STRAJKU I AKCJI PROTESTACYJNYCH OSÓB WYKONUJĄCYCH PRACE ZAROBKOWĄ POZA STOSUNKIEM PRACY}

Streszczenie. Niniejsze opracowanie podejmuje temat rozszerzenia uprawnień do prowadzenia sporu zbiorowego pracy na osoby wykonujące pracę zarobkową na podstawie umów cywilnoprawnych, po wejściu w życie ustawy z 5 lipca 2018 r. o zmianie ustawy o związkach zawodowych oraz niektórych innych ustaw. Autor rozważa pytanie, czy i w jakim zakresie prawo do strajku i akcji protestacyjnych, przewidziane przez ustawę z 23 maja $1991 \mathrm{r}$. o rozwiązywaniu sporów zbiorowych, rozciąga się na cywilnoprawnych wykonawców pracy. Prezentowane jest stanowisko, że odpowiednie stosowanie wymienionej ustawy do wskazanego kręgu adresatów nie może oznaczać de lege lata pozbawienia ani ograniczenia przysługującego im prawa do strajku i akcji protestacyjnej. Rozwiązania wdrożone przez polskiego ustawodawcę w odniesieniu do

${ }^{*}$ University of Wrocław, Faculty of Law, Administration and Economics, Department of LaborLaw; artur.tomanek@uwr.edu.pl 
osób wykonujących pracę poza stosunkiem pracy są bardziej korzystne i dalej idące w porównaniu do wymagań wynikających z wiążących Polskę aktów międzynarodowego prawa pracy. Rysują się jednak szczegółowe problemy stosowania do tych osób niektórych regulacji zamieszczonych w ustawie o rozwiązywaniu sporów zbiorowych, co wynika z tego, że indywidualny stosunek prawny pomiędzy tymi osobami a podmiotami je zatrudniającymi jest oparty na przepisach prawa cywilnego, a nie na przepisach Kodeksu pracy.

Slowa kluczowe: spór zbiorowy pracy, związek zawodowy, prawo do strajku, akcja protestacyjna, umowa cywilnoprawna, stosunek pracy.

\section{THE SUBJECTIVE SCOPE OF POLISH COLLECTIVE LABOUR LAW}

The status of persons performing gainful employment under civil law contracts is one of the central issues of the contemporary Polish labour law. The collective labour law has been long considered an area of labour law which has not been dedicated to the workers performing their duties on civil law basis. In the recent period this situation has began to change as a result of an attitude of International Labour Organization towards the civil law workers. It gave rise to the process of an extention of collective labour law rights to the above-mentioned circle of persons.

This text is focused on the issue whether the right to strike and to take an industrial action may be extended to persons performing paid work on civil law basis. To this aim the formal-dogmatic method of an analysis of legal text is used. This method has to be supplemented by the axiological analysis of the purpose of legal regulation. It is also of a key importance to take into account an international law context of Polish regulation.

The essential part of considerations must be preceded by the remarks on the scope of collective labour law regulations, with particular reference to persons employed on civil law basis. According to the legal status effective before the enforcement of the Act of 5 July 2018 amending the Act on Trade Unions and Certain Other Acts (Journal of Laws 2018, item 1608), the subjective scope of the coalition rights covered only certain categories of persons performing gainful employment outside the employment relationship. The aforementioned amendment brought about a breakthrough change. The newly added provision of Article 1'(1) of the Act on Trade Unions of 23 May 1991 (consolidated text: Journal of Laws 2019, item 263 as amended; hereinafter: ATU) has shaped the definition of a person performing gainful employment. Coalition rights were given to a significantly expanded circle of persons covered by this definition. Other regulations that make up the collective labour law framework were also applied to these persons. In the area of collective labour disputes, this is determined by Article 1 of the Act of 23 May 1991 on Resolution of Collective Labour Disputes (consolidated text: Journal of Laws 2020, item 123; hereinafter: ARCD), according to which a collective dispute between employees and their employer(s) may relate to the 
working conditions, pay or social benefits of employees or other groups who have the right to join a trade union. According to the amended Article of 6 ARCD, the provisions of this act, which refer to employees, are applicable to persons other than employees who perform gainful employment, as referred to in Art. $1^{1}(1)$ of ATU.

The circle of persons performing paid work who are beneficiaries of the collective labour law solutions (collective employment law) is defined very broadly in Article 1'(1) of ATU. Apart from employees (Article 2 of the Labour Code; hereinafter: $\mathrm{LC}$ ), this provision includes persons meeting the following conditions: 1) providing paid work for remuneration on a basis other than the employment relationship, 2) not employing other persons, regardless of the basis of employment, 3) having such rights and interests related to the performance of work that can be represented and defended by a trade union.

Undoubtedly, the standard of Article 1'(1) of ATU covers persons performing "work" for the benefit of other entities on the basis of named and unnamed civil law contracts of payable nature, regardless of whether it is a result agreement or a service contract. In the light of the above provision, the circle of subjects benefiting from coalition rights also include natural persons conducting business activity within the meaning of the Act of 6 March 2018 on the Law of Entrepreneurs (consolidated text: Journal of Laws of 2019, item 1292, as amended), unless they employ other persons as part of this activity. It should be noted that the conduct of business activity by natural persons is manifested by the performance of work (services), on the basis of civil law contracts concluded with other persons (mandators, ordering parties, etc.). Similar contracts are concluded by service providers who are not entrepreneurs with the difference that the business activities of natural persons are organised, performed in their own name and on a continuous basis (Article 3 of the Law on Entrepreneurs). Therefore, performance of services or other activities under contracts concluded as part of the business activity falls within the concept of "paid work" of natural persons referred to in Article 1'(1) of ATU.

Article $1^{1}(1)$ of the above-mentioned act contains a criterion referring to the professional interest of the natural person that can be represented and defended by a trade union. A certain usefulness of this requirement for the clarification of the circle of the protected persons cannot be excluded. While an entrepreneur being a natural person has only an economic interest, he should not be an addressee of collective labour law solutions modelled on the rights of employees. However, some authors have aptly questioned the practical usefulness of this criterion, indicating that its introduction proves that the legislator was concerned with the broadest possible definition of the subjective scope of the coalition (Stelina 2018, 26). In particular, it does not seem difficult for an individual entrepreneur to plausibly ensure that his (her) professional interest protected by collective labour law is linked with the level of remuneration or guaranteeing safe and hygienic working conditions in the workplace (see Article 304[3][2] LC). 
It should be emphasized that the legislator has resigned from introducing further criteria, apart from personal performance of work, which would limit the subjective scope of application of Article $1^{1}$ point 1 of ATU. Therefore, the solutions of the collective labour law are addressed to the dependent and independent performers of gainful work, reserving in both cases the negative condition that a person does not act as an employer. It should be noted that a dependent contractor (dependent self-employed person) is defined in the literature as a person who earns all or most of his income from work (services) performed for a specific entrepreneur (Boruta 2005, 3; Gersdorf 2012, 28; Duraj $2019,11)$.

This paper, due to its scope, focuses on the status of civil law contractors, omitting those who provide paid work on other grounds, including officers of the militarised services, covered by autonomous regulations of service pragmatists.

\section{ARE PERSONS PERFORMING GAINFUL EMPLOYMENT OUTSIDE THE EMPLOYMENT RELATIONSHIP ENTITLED TO STRIKE?}

In the judgment of 2 June 2015, K 1/13 (Constitutional Tribunal Case Law - Series A 2015, No. 6, item 80), the Constitutional Tribunal ruled that persons performing gainful employment outside the employment relationship should have the right to associate in trade unions. However, it did not declare whether these persons should be granted the right to assert their rights and interests by way of a collective dispute, including the right to initiate its confrontational stages in the form of a strike or industrial action; this issue was outside the scope of the Tribunal's consideration. The international law regulations in force in Poland do not provide a direct answer to this question either. The right to strike has not been explicitly stated in the International Labour Organization (ILO) conventions. However, it is considered that it results indirectly from Article 3 of ILO Convention No. 87 (Journal of Laws 1958, No. 29, item 125), which grants employees' organisations the right to organise their own activities. Similar importance is attached to the provisions included in some other ILO conventions. The right to strike is also expressly granted in other international labour law acts (see closer Żołyński 2013, 200-203). For instance, Article 6(4) of European Social Charter (Journal of Laws 1999, No. 8, item 67) states that the contracting parties recognize the right of workers and employers to collective action in cases of conflicts of interest, including the right to strike, subject to obligations that might arise out of collective agreements previously entered into. This right shall not be subject to any restrictions and limitations, except such as are prescribed by law and are necessary in a democratic society for the protection of the rights and freedoms of others or for the protection of public interest, national security, public health, or morals (Article 31[1] of ESC, Part II). 
Article 9(1) of ILO Convention No. 87 grants the national legislator the option to restrict the trade union rights of officers of the armed forces and the police. This provision would indicate that restrictions cannot be imposed on other categories of workers. It seems, however, that such a proposal would lead to an improper simplification of the discussed problem. Firstly, as noted above, the Convention does not speak of the right to strike (but only the right of coalition). Secondly, it is not irrelevant whether we are dealing with workers in the strict sense of the word (performing subordinate work), who remain in the primary circle of interest of the Convention's standard-setter, or with other persons providing gainful activity who are covered by the Convention through an inclusive interpretation of the term worker, made at a later stage of application of the Convention.

In my opinion, it is unacceptable, in the light of the provisions referred to above, to generally deprive civil law contractors of the right to initiate and conduct a collective labour dispute. It would be difficult to accept granting the right of association while excluding the basic tools enabling the defence of the rights and interests of the associated persons. On the other hand, it seems that the national legislator has more flexibility as far as confrontational methods of collective labour dispute are concerned.

The issue of collective disputes was not directly addressed by the recommendation of the ILO's Committee on Freedom of Association of 15-30.03.2012 (ILO Report of 313th Session, Geneva 15-30.03.2012, Case No. 2088, ilo.org.pl, accessed: 15.10.2019), which became a motive for the OPZZ (National Trade Union Agreement) to submit an application to examine the constitutionality of the provisions of the Act of Trade Union, decided by the judgment of the Constitutional Tribunal of 2 June 2015, K 1/13. On the contrary, the ILO experts' report summarizing the so-called Technical Assistance (Mission Report), conducted on 14-16 May 2014 on the initiative of the Polish government, with the consent and participation of representatives of trade unions and employers' organizations (http://www.solidarnosc.org.pl/images/files/zalaczniki/ Pomoc techniczna MOP.pdf., accessed: 15 October 2019; see closer PodgórskaRakiel 2014), may be helpful for considerations of this paper. The report refers to the situation of contractors of "genuine" civil law contracts, distinguished from the apparent contracts, which are in fact a form of concealment of employment of a labour nature. Genuine civil law contracts with very different circumstances would be, in the opinion of ILO experts, difficult to regulate under the Act on Trade Unions. It was observed by ILO experts that many sections of the above act would be amended to adapt to these different circumstances and this process would be very time-consuming. Hence, it would be preferable and simpler to grant broadly to all workers the right to organize in a global provision of ATU and let the social partners and the courts address application issue (cf. Jończyk 1984, 348). A provision of this act could also acknowledge that all trade unions had the right to enter into collective disputes, since it would be difficult to apply the entire 
ARCD to relations other than employment relationships (ILO Mission Report, point 11).

The above report also stresses that all workers in broad sense of the term should have the right to organize, enjoy protection of their organizational rights and have a collective voice. However, the ILO supervisory bodies do not necessarily expect that this rights be granted through the Act on Trade Unions to self-employed and persons working under civil law contracts. In particular there should be a possibility to exercise a form of industrial action in a collective way but not necessarily under ARCD. For example, the right to organize would allow musicians to engage collectively with the Government and the major players in this industry since they have not a single employer (ILO Mission Report, point 7).

Nevertheless, the Polish legislator decided to include in ARCD a regulation relating to non-employee performers (see Grzebyk, Pisarczyk 2019, 95, who assessed this solution as 'fairly bold', indicating that the legislator did not attempt to introduce any restrictions in this respect). The amending Act of 5 July 2018 amended Article 6 of ARCD by extending the existing scope of reference used in this Act to the term "employee". In accordance with the amended wording of Article 6, the provisions of ARCD, in which the employees are referred to, apply accordingly to persons other than employees who perform paid work referred to in Article 1'(1) of ATU.

The "appropriate" application of the provisions of the ARCD to employees presupposes that the specificity of carrying out gainful employment on a basis other than the employment relationship must be taken into account. In my opinion, it should be ruled out that the proper application of the provisions of ARCD is understood as a permission to exclude the right to strike of certain categories of non-employees. It cannot be denied that the proper application of the provisions may also consist in a refusal to apply the rules falling within the scope of reference. However, due to the nature of the right to strike, which is given a free dimension, it would be necessary for the legislator to explicitly exclude the provisions on strike in relation to the group of employees which is distinguished by the legal form (basis) of performing paid work. This conclusion is supported by the aforementioned provisions of international law, which describe the exclusion of coalition rights in terms of derogation from the rule, justified by important reasons of a general social nature. The provision of Article 59(3), sentence 2 of the Constitution of the Republic of Poland has an even more categorical meaning. According to this provision, the act, for reasons of public interest, may restrict or prohibit a strike with respect to certain categories of workers or in certain areas. In the light of the constitutional norm referred to, the provision of an ordinary statute limiting the right to strike should meet two requirements. First, the provision should take the form of excluding or restricting the right to strike, and second, it should specify the category of workers covered by such restriction. 
Therefore, taking into account the above considerations, the basis for exclusion of strike rights of persons who are not employees can only be the provision of Article 21 of ARCD, which constructs a catalogue of exclusions by the nature of the work performed (in specific industries or units or related to specific worksites), and not by the legal form of performing work.

\section{THE PROBLEM OF AN EMPLOYER OF A PERSON WHO IS ENGAGED IN GAINFUL EMPLOYMENT OUTSIDE THE EMPLOYMENT RELATIONSHIP}

The issue of the party of a collective dispute is undoubtedly within the "general part" of the collective labour law, going beyond the horizon of the deliberations about the confrontational stage of the dispute. Despite this reservation, the discussion of this issue within the framework of this study is purposeful, as the conditions related to the party of a collective dispute have an impact on the various stages of the dispute, also affecting the exercise of the right to strike.

Pursuant to the amendment act of 5 July 2018, there has been a change in the definition of a legal employer in Article 5 of ARCD. This change is a reflection of the full extension of coalition rights to persons performing work on a basis other than the employment relationship. The above-mentioned provision in its current wording refers when defining an employer to Art. $1^{1}(2)$ ATU, in force since 1 January 2019. The latter provision states that whenever this Act refers to an employer, it should be understood as an employer within the meaning of Article 3 of LC and an organizational unit, even if it has no legal personality, as well as a natural person, if they employ a person other than an employee who performs gainful employment, regardless of the basis of such employment.

The application of this definition to non-employee relations poses significant problems, especially with regard to self-employed persons (in particular carrying out economic activities), who are potential subjects of collective dispute and the right to strike on the employee side. On a general level, it should be noted that the earlier contexts of using the terms "employer" and "employment" referred to the party of employment relationship or to the entity to which the civil law contract is provided. The employing entity was in each case a person for the benefit of whom work is provided under a specific legal relationship. By contrast, a person conducting economic activity has no employer, as he or she performs this activity for their own benefit. The labour law literature has developed the term "self-employed", meaning the persons who "employ themselves" (see terminological remarks made by Jończyk 2000, 40). It means that they do not perform their activities for the benefit of a person who could be compared to an employer. This statement applies in particular to the independent self-employed person.

In the existing legal conditions, set out by Article $1^{1}(2)$ of ATU, it should be considered that employers of natural persons conducting individual activities 
(entrepreneurs) are organizational units and natural persons with whom these entrepreneurs conclude named and unnamed civil law contracts, in order to provide them with services in the broad sense. Employers within the meaning of Article 1'(2) of ATU (in connection with Art. 5 of ARCD) are, therefore, in fact, the contractors of these persons on the economic market. Since the definition of a person performing gainful employment (Article $1^{1}(1)$ of ATU) does not apply the economic criterion (e.g. by indicating that such a person is bound by a legal relationship with only one contractor), these persons may have as many employers as they have contractors, which may potentially result in organisational problems in conducting a collective labour dispute, not excluding strike action. A separate issue, which due to lack of space will not be developed in these deliberations, is the adoption by the legislator of the so-called management concept of an employer when formulating the definition of Article $1^{1}(2)$ of the above-mentioned act. This leads to the conclusion that the employer of a person conducting a nonemployee gainful activity may be in concreto not a legal person, but an internal organizational unit of that person which is deprived of the status of civil law subject (see closer Tomanek 2019).

\section{ADEQUATE APPLICATION OF THE PROVISIONS ON STRIKE AND INDUSTRIAL ACTION TO PERSONS ENGAGED IN GAINFUL EMPLOYMENT OUTSIDE THE EMPLOYMENT RELATIONSHIP}

Pursuant to Article 6 of ARCD, the provisions of this act referred to as employees shall apply accordingly to persons other than employees who perform gainful employment referred to in Article 11(1) of the Act. The provision of Article 6 of ARCD belongs to the referral provisions of broad significance, as it does not contain, apart from the element of referral, the autonomous content necessary to build a legal norm. The reference is of an internal nature (as it concerns the provisions contained in the same legal act) and a descriptive one, as it does not indicate the scope of application by specifying the numbers of the editorial units of the act, but by using the term "employee". The reference scope includes the status of a person performing other paid work, referred to in Article 1'(1) of ATU. The possibility to construct such a reference is provided for in $\S 156(4)$ of the Appendix to the Regulation of the Prime Minister of 20 June 2002 on the Principles of Legislative Technique (consolidated text: Journal of Laws of 2016, item 283).

A certain doubt may be raised by a narrow definition of the scope of application of the reference norm, which is fulfilled only if the applicable provisions use the term "employee", referring to persons performing gainful employment outside the employment relationship. A literal understanding of Article 6 of ARCD would mean that the provisions of that act which do not use the term "employee" are left out of the scope of the referral. As an example, we 
can mention Article 18 of this act, which states that "Participation in a strike is voluntary" and Article 24, according to which "Trade unions decide on the creation and use of strike funds. These funds are not subject to execution". A purposeful interpretation, however, allows the above provisions to be included in the scope of reference, since they regulate the employee's right to strike or the consequences caused by the strike.

What is essential, however, is the fact that the provision of Article 6 of ARCD speaks of "appropriate" application of the provisions of this act, in which the employees are referred to, to persons other than employees who perform gainful employment.

In the legal theory literature it has been noted that the reservation of appropriateness used by the legislator is aimed at sensitising the interpreter of the provisions to the specific nature of the reference, i.e. that it is not a direct reference, but an indirect one. In the cases in question, the functional, purposeful and axiological interpretation must take precedence over the literal interpretation, which is somewhat secondary in the process of the clarification of the provisions speaking of appropriate applications of other provisions (Hauser 2005). It means that an interpreter should take into account the specific nature of legal relationships involving the performance of gainful employment outside the employment relationship.

In the literature, it is emphasized unanimously that the result of proper application of the provision may be: 1) the application of specific provisions directly; 2) their application after appropriate modification, taking into account the specificity of a given legal institution; 3) total inapplicability of a specific provision (Nowacki 1964, 370-371).

With regard to the situation ad 2), it should be agreed that the modification of a properly applied provision may require not only the necessary correction of its hypothesis, but also the adjustment of its disposition by making the necessary changes to it, depending on the specificity of the scope of the reference (Masewicz 1977, 836). However, the boundary of such changes should be the essence of the content of the reference provision and the function of the legal norm derived from it.

\section{CONDITIONS FOR EXERCISING THE RIGHT TO STRIKE BY PERSONS ENGAGED IN GAINFUL EMPLOYMENT OUTSIDE THE EMPLOYMENT RELATIONSHIP}

According to above considerations, the provisions of ARCD do not authorize such limitations to the right to strike of persons performing work outside the employment relationship, which arise solely from the legal form of their employment. Recourse to strikearms may be a particularly dysfunctional solution in the case of self-employed persons who are not economically dependent 
on a single contractor. An example would be a collective action of persons performing construction work or repair work under an individual housing project. The similar situations cannot be ruled out a priori. Therefore, the provisions of ARCD concerning the legality of the right to strike should be analysed in the context of the reference contained in Article 6 of ARCD, assuming appropriate application of these provisions to persons performing gainful employment outside the employment relationship.

This analysis leads to the conclusion that the regulations of Article 17-22 of ARCD will be applied to non-employee contractors directly or after the necessary scope of their modification. An example of direct application is the provision of Article 18 of ARCD, which provides for voluntary participation in a strike. However, the obligations of strike organizers, as set out in Article 21 of ARCD, require modification. If the strike is attended by persons performing work on other grounds than the employment relationship, there are no grounds for using the terms "employing establishment" and "manager of employing establishment" (Article 21(1) in fine of ARCD), with strictly employee-related connotations. Therefore, the striking party's partner in performing the necessary cooperation during the strike will be for instance manager of the undertaking or the manager of the construction site where the civil law contractors of the project went on strike.

The subjective and objective prohibitions on strike laid down in Article 19 of ARCD shall apply equally to civil law contractors employed in specific positions and in the institutions mentioned in that provision. Persons who are not employees, working for the benefit of the militarised formations referred to in Article 19(2), retain the right to strike, but it is not permitted to exercise this right in these formations.

The application of the provision of Article 23 of ARCD to civil law contractors is questionable. Paragraph 1 of this provision indicates that an employee's participation in a strike organised in accordance with the provisions of this act does not constitute a breach of their employment obligations. According to paragraph 2, during such a strike, an employee retains the right to social security benefits and rights stemming from the employment relationship, except for the right to remuneration. The period of break in the performance of work is included in the period of employment at the workplace.

This means that an employer has no grounds for applying sanctions against an employee who took part in a legal strike. However, the provisions of civil law do not know the concept of "breach of employment obligations". Violation of these obligations can only be the basis of an employee's liability if it is based on a guilty plea. On the contrary, civil law often uses the principle of absolute liability for nonperformance or improper performance. This principle may result both from the contract (Article $353^{1}$ of the Civil Code) and from the content of the provisions of the Civil Code, operating specific sanction constructions. As an example, Article 635 of the Civil Code may be invoked, which allows the orderer to withdraw 
from the specific task contract if the performer delays the commencement or completion of the work to such an extent that it is unlikely to be completed within the agreed time. The orderer's exercise of the right to withdraw from the contract does not depend on the possibility of charging the party accepting the contract with a breach of due diligence. Therefore, the question arises whether the orderer is entitled to use the right of withdrawal if the reason for the contractor's delay was participation in a legal strike (cf. Baran 2019, 491, who indicates that participation in such a strike does not constitute a violation of civil law obligations). It shows that the proper application of Article 23 of ARCD to persons performing work under civil law contracts may encounter significant difficulties. It should be also noted that the second sentence of Article 23(2) of ARCD refers to the concept of employee's length of service, which calls into question the possibility of its reference to civil law contractors.

It should be added that the provisions of Articles 24 and 25 of ARCD, regulating the creation of strike funds by a trade union and the right of persons performing work on a basis other than an employment relationship to carry out an industrial action, may be applied without significant changes to persons performing work on a basis other than an employment relationship.

\section{BIBLIOGRAPHY}

Baran, Krzysztof W. 2019. Ed. Zbiorowe prawo zatrudnienia. Komentarz. Warszawa: Wolters Kluwer.

Boruta, Irena. 2005. "W sprawie przyszłości prawa pracy”. Praca i Zabezpieczenie Społeczne 4: 3-13.

Duraj, Tomasz. 2019. "Przyszłość cywilnoprawnych stosunków zatrudnienia”. Acta Universitatis Lodzensis. Folia Iuridica 88: 5-16.

Gersdorf, Małgorzata. 2012. Ed. Zatrudnieni i zatrudniający na aktualnym rynku pracy. Warszawa: LexisNexis.

Grzebyk, Piotr. Łukasz Pisarczyk. 2019. "Krajobraz po reformie. Zbiorowa reprezentacja praw i interesów zatrudnionych niebędących pracownikami”. Praca i Zabezpieczenie Społeczne 1: $81-98$.

Hauser, Maria. 2005. „Odpowiednie stosowanie przepisów prawa - uwagi porządkujące”. Przegląd Prawa i Administracji 65: 151-168.

Jończyk, Jan. 1984. Prawo pracy. Warszawa: Państwowe Wydawnictwo Naukowe.

Jończyk, Jan. 2000. "Umowy o zatrudnienie w aspekcie rekodyfikacji prawa pracy”. In Szczególne formy zatrudnienia. Edited by Zdzisław Kubot. 39-52. Wrocław: Wydawnictwo Uniwersytetu Wrocławskiego.

Masewicz, Walery. 1977. In Kodeks pracy. Komentarz. Edited by Jan Jończyk. Warszawa: Wydawnictwo Prawnicze.

Nowacki, Józef. 1964. "Odpowiednie stosowanie przepisów prawa”. Państwo i Prawo 3: 367-376.

Podgórska-Rakiel, Ewa. 2014. "Konieczność nowelizacji prawa polskiego w kwestii wolności związkowych z perspektywy Międzynarodowej Organizacji Pracy”. Monitor Prawa Pracy 10: 509-514. 
Stelina, Jakub. 2018. In Zbiorowe prawo zatrudnienia. Edited by Jakub Stelina, Jakub Szmit. Warszawa: WKP.

Tomanek, Artur. 2019. "Wątpliwości wokół nowej definicji pracodawcy w prawie związkowym". Praca i Zabezpieczenie Spoleczne 3: 19-27.

Żołyński, Janusz. 2013. Strajk $i$ inne rodzaje akcji protestacyjnych jako metody rozwiazywania sporów zbiorowych. Warszawa: Lex a Wolters Kluwer business. 